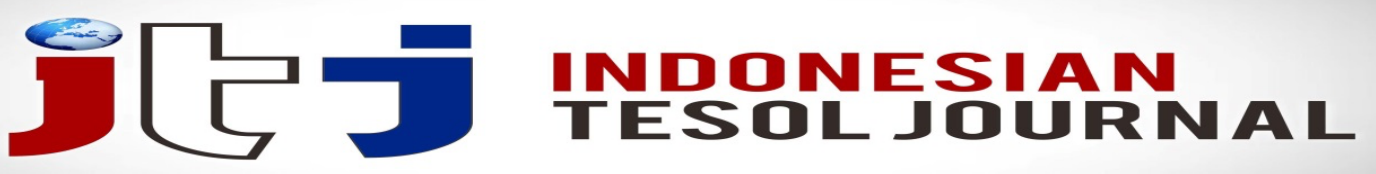

e-ISSN: 2622-5441(Online) Journal homepage: https://ejournal.iainpalopo.ac.id/index.php/ITJ/index

\title{
Exploring the Perceptions of Moroccan EFL Teachers Towards Task-Based Language Learning
}

\author{
Mohammed Mettar \\ Sidi Mohamed Ben Abdellah University, Morocco
}

Abstract: Moroccan students do not have many opportunities to use English outside the classroom setting. The adoption of task-based language learning (TBLL) is deemed to be an appropriate language instructional method for the Moroccan EFL context. Hence, teachers are explicitly urged in the official Moroccan English language guidelines documents to adopt tasks in their teaching practices. However, no known empirical research has been conducted to investigate teachers' perceptions and use of TBLL. To fill this gap, this study attempted to investigate high school EFL instructors' familiarity with TBLL and their views on the use of tasks in their classrooms. An online survey provided quantitative data from 90 participants. Results showed that although Moroccan EFL teachers have a good understanding of the key concepts of this approach, their use of tasks is limited. Lack of taskbased materials, large class sizes, and students' use of their mother tongue to complete the task are identified as the main obstacles facing a high level of use of tasks in teachers' classroom practices. Several implications for the successful integration of TBLL in the Moroccan EFL context are suggested at the end of the article.

Keywords: EFL teachers; Task-Based Language Learning (TBLL); task; English.

\section{INTRODUCTION}

The linguistic revolution during the 1970s gave birth to the Communicative Approaches to language instruction (Brown, 2006). Henceforth, developing learners' communicative competence, rather than only their linguistic competence, has become the ultimate goal of language learning and teaching approaches and methods (Brown, 2006; Larsen-Freeman \& Anderson, 2011; Richards \& Rodgers, 2001). In light of recent research, students do not first acquire forms and then learn how to use them in communication. Rather, they "discover the language system itself in the process of learning how to communicate" (Ellis, 2003, p. 28). Language learning is claimed to be developed independently from instruction (Skehan, 1996; J. Willis, 2004). Accordingly, Willis (1996) argue that classroom time is better spent in increasing exposure to the target language and getting students to use the language themselves. The teacher's main role is not to teach, but rather to provide students with opportunities to engage in what Ellis (2003) calls meaning-making. 
One of the approaches to second and foreign language learning that subscribes to this language learning philosophy is Task-Based Language Learning. It is worth mentioning that this method is not a reaction to Communicative Language Teaching (CLT), rather a development within it (Larsen-Freeman \& Anderson, 2011; Richards \& Rodgers, 2001). Both of them place more emphasis on interaction, conversation, and language use, and not learning the language itself (Lightbown and Spada, 2006). Put differently, both of them view language as a means of communication rather than a subject of study.

Learning foreign languages is regarded as one of the important axes of the Moroccan education reform. The strategic vision 2015-2030 has placed considerable attention on English learning in particular. Given the fact that students have little exposure to English outside school, one of the key assumptions of the Moroccan EFL curriculum is that "language acquisition is fostered by engaging learners in real tasks" (MoE, 2009, p. 16). Furthermore, EFL teachers are urged explicitly to use and design tasks as they are defined as important in developing students' communicative skills in the English language guidelines for secondary schools (MoE, 2007).

Surprisingly, no research has been carried out to investigate EFL teachers' views on the implementation of TBLL in the Moroccan EFL context. To fill up this gap, this present study aimed to examine teachers' understanding of the key concepts of TBLL. It also attempted to identify the factors that motivate or inhibit teachers from utilizing tasks in their practices. To meet these objectives, this study sought to answer the following specific research questions:

1) To what extent are Moroccan EFL teachers familiar with the key concepts of TBLL?

2) What do teachers perceive as factors that enhance the adoption of TBLL in the Moroccan EFL context?

3) What do EFL teachers perceive as obstacles to implementing TBLL?

\section{LITERATURE REVIEW}

\section{Theoretical background}

Task-Based language learning is considered as an updated or a new version of the Communicative Approach that has achieved worldwide popularity recently (Littlewood, 2004). In an interview with Manuel Jimenez Raya, Rod Ellis described it as a worthy approach that is endorsed by both considerable second language acquisition (SLA) studies and education theories that "view instruction from an interpretative rather than transmission perspective" (Raya, 2009, p. 13). Some of the SLA assumptions that support the pedagogical significance of the Task-Based Approach are:

- Learning a language takes place independently from teaching (Skehan, 1996; J Willis, 2004) 
- Language learning does not necessarily follow a specific order (J Willis, 2004).

- learning is more effective when students discover the language system in communication (Ellis, 2003; J Willis, 2004)

The high interest in Task-Based Language Teaching stems from the fact that it addresses various current pedagogical issues such as the importance of the affective factors, learner centeredness, and the development of both accuracy and fluency (Ellis, 2003). Similarly, Nunan (2004, (p. 1) claims that this promising approach has emerged essentially to endorse some principles and practices such as: "1) the provision of opportunities for learners to focus not only on language but also on the learning process itself; 2) an enhancement of the learner's personal experiences as important contributing elements to classroom learning; 3) an emphasis on learning to communicate through interaction in the target language; and 4) the linking of classroom language learning with language use outside the classroom)".

\section{Defining Pedagogical task}

The core concept of the Task-Based Approach is undoubtedly the task. There is not an agreed-upon definition of this controversial concept among researchers. Littlewood (2004) claims that it "ranges along a continuum according to the extent to which the communicative purpose is considered an essential criterion" (p. 320). Such a conceptualization of the term task makes it too broad and elusive in the sense that it becomes a word that encompasses "almost anything that might happen in a classroom" (Willis and Willis, 2001, p. 173).

In order to avoid confusion that could result from approaching the concept of task from all the various angles, the primary goal of this research is to examine how a small number of researchers have approached it. The following section discusses how tasks are comparable to language exercises and language communicative activities.

\section{Language Exercise}

An exercise might be the oldest language tool used in language learning. It refers to a piece of classroom work that involves the learners in manipulating "some aspects of the linguistic system" (Nunan, 2004, p. 214). The context is of no importance as exercises "call for primarily form-focused language use" (Ellis, 2003 , p. 3). That is to say, the main and only focus on exercises is developing students' accuracy. Language exercises do not have in any way a communicative purpose. They are always corrected immediately and therefore students' answers are either correct or incorrect.

\section{Language Communicative Activity}

A communication activity is a piece of classroom work that places focus on both form and meaning. Nunan (2004) considers it as a "half-way house" between exercises and tasks. Like language exercises, communicative activities provide students with an opportunity to study and master specific language forms. 
They are similar to tasks by having "an element of meaningful communication" (p. 24).

\section{Pedagogical Task}

Ellis (2003) defines a task as "a tool for engaging learning in meaningmaking and thereby for creating the conditions for language acquisition" (p. 319). For Nunan (2004), it refers to "a classroom work that involves learners in comprehending, manipulating, producing or interacting in the target language while their attention is focused on mobilizing their grammatical knowledge in order to express meaning" (p. 4). In this light, a task is a classroom work in which meaning is primary. Hence, Willis and Willis (2001) stress that the use of the term task should be restricted to activities that aim at developing students' communicative skills and authentic use of language.

In other words, a task is not about the practice of a particular linguistic feature as it is the case in language exercises and communicative activities. Rather, it drives students to use language in the way it is used in the real world (Ellis, 2003). While performing a given task, students' attention is essentially on expressing meaning without being compelled to use any particular language forms to complete it. However, this does not mean that accuracy is neglected completely. After the students complete the task, teachers can work with students on some language forms.

Identifying some of the key characteristics of a pedagogical task is necessary and important; otherwise, the term would extend to include any activity that aims at the development of fluency (e.g., free discussions and debates), which would imply that "the concept has no limits and is therefore of little meaning" (Littlewood, 2004, p. 321). To begin with, the meaning is of paramount importance in tasks. Therefore, it needs to contain a "gap" (e.g., information gap, opinion gap, reasoning gap) with the objective of engaging learners in using language communicatively and not mechanically (Ellis, 2015; Skehan, 1996).

Moreover, a task has a clearly defined outcome (Ellis, 2003). It provides students with an opportunity to use language with a purpose in mind and a goal to achieve rather than just using the language for its own sake (Nunan, 2004). This characteristic is very important as it serves to make students perceive language as a tool of communication and thus concentrate on using it rather than studying it. It also serves to signal that the task has been completed. This is of a high priority since the assessment should be done in terms of the outcome (Skehan, 1996).

Additionally, a task prepares learners for real-world communication. It is true that the teacher can predispose them and pre-teach them some grammatical structures and lexis they may need, but the learners are free to use whatever language they want to perform the task (Ellis, 2003; Nunan, 2004; D. Willis \& Willis, 2001). It is worth mentioning that tasks are not restricted to those that resemble the tasks people undertake in their life such as completing a form (Nunan, 2004). The idea here is that tasks focus on authentic and not artificial language use and engage students in meaningful interaction with the purpose of enabling them to communicate with ease outside the walls of the classroom. Last 
but not least, a task is a work plan that can involve any of the four language skills (Ellis, 2003). Students might be required to listen to a conversation, read a text, give an oral presentation, write a report, or a combination of all of them.

\section{The Task-Based Instruction Framework}

The Task-Based Approach suggests a completely new and different methodology to language teaching. Admittedly, there is no one type of task-based lesson format (Ellis, 2009). Still, there is a general agreement on a three-phase procedure (Willis, 1996). The following figure displays the three phases lesson format clearly.

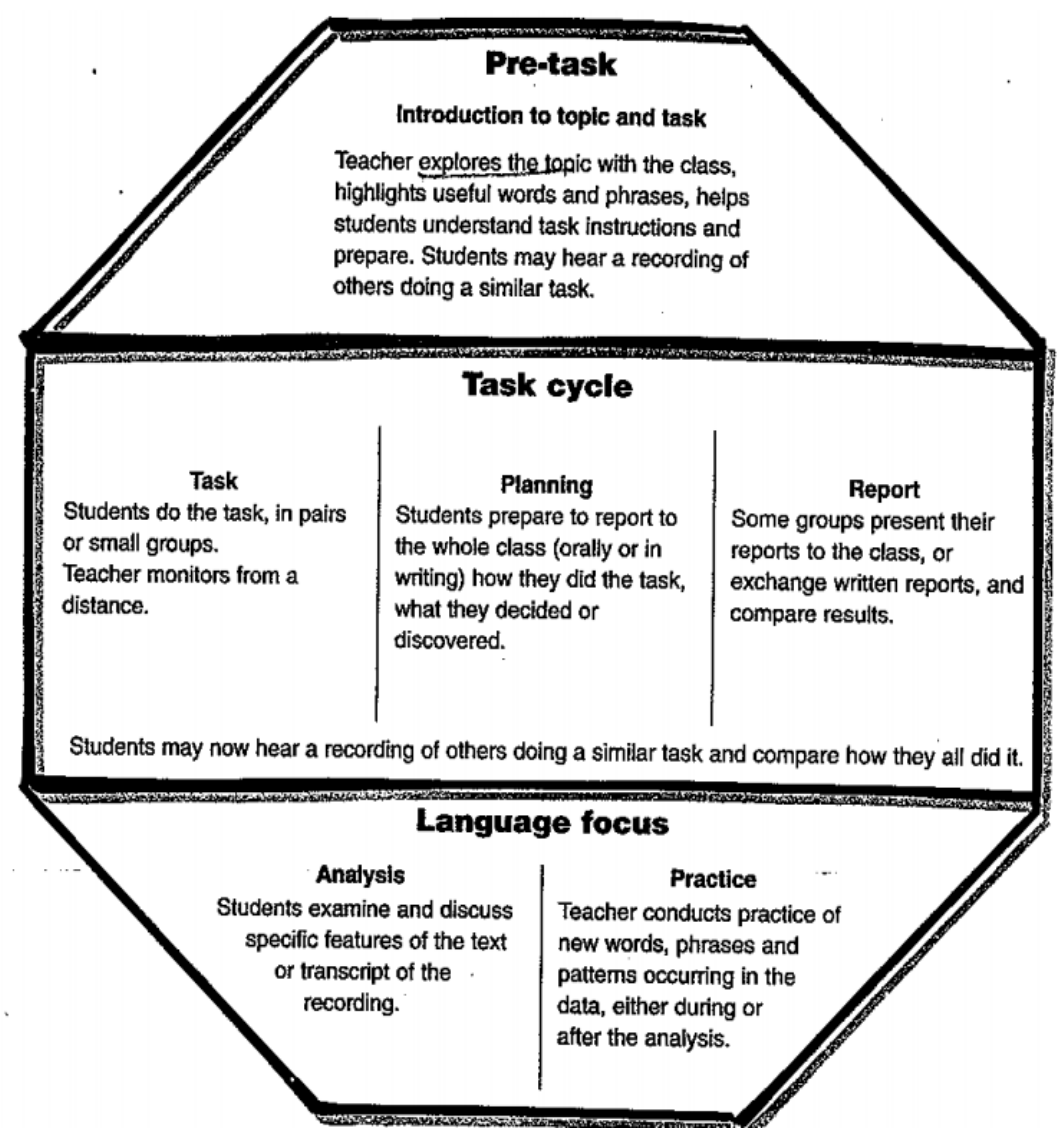

Figure 1. Components of the TBLL Framework, source (Willis, 1996, p. 38)

The TBLL framework stands in total opposition with the old traditional Presentation, Practice, and Production (henceforth, PPP) model. The latter consists of three phases as well: a language item is presented by the teacher, practiced in a controlled manner, and followed by opportunities for free production. While the PPP model moves students from accuracy exercises to fluency activities, the TBLL framework moves them from fluency to accuracy. Ellis (2003) acknowledges that it is hard to assert that the TBLL model is more effective than the PPP model due to the impossibility of controlling all the variables while conducting a comparative study of the two models. Still, he 
confirms that many studies show that TBLL results in learning and he gives as an example of the success of immersion programs in Canada as they are in effect a form of TBLL.

The significance of the TBLL framework lies in the fact that it would make students consider language primarily as a means of communication rather than a subject of study. The students' focus in the TBLL model is on completing the task while it is on the accurate usage of some language forms in the PPP model. Moreover, one cannot deny the fact that the three phases in the TBLL model are consistent with learner centeredness. The students are clearly in charge and responsible for their learning. They are interactors and negotiators who do not only take but also give (Nunan, 1991). The teacher's role is to accompany them in their journey of discovery which is not the case in the traditional PPP procedure in which the teacher closely controls their learning by presenting them with a set of language items and asking them to practice them. Thus, learners try hard to match what their teacher expects from them.

The task cycle is the core part of the TBLL model. It provides students with an opportunity to work together and collaborate, which is consistent with Vygotsky's theory of social learning. Through working in pairs or groups to complete the task, students are not supposed to practice particular forms but to use language naturally which would lead them certainly to make use of what Long (1983) calls conversational modifications (e.g., comprehension checks, clarification, paraphrasing, self-repetition). This results in learning not only the intended language forms but also other language items as well. Jordan (2004) posits that the Task-Based Approach is consistent with Long's interaction hypothesis since "tasks can be selected and manipulated so as to maximize the opportunities for learners to turn input into intake" (p. 221).

While working together in pairs or groups, students learn a great deal from each other. However, it is possible that they pick up mistakes as well. Therefore, one of the teacher's roles is to provide them with corrective feedback while they are doing the task without interfering with the communication flow. The post-task phase is devoted not only to practice the language forms that were intended to be studied but also to raise students' awareness of the mistakes they made during the task cycle phase. The focus is on the development of language in general and not necessarily of a specific structure.

\section{Research on TBLL in EFL Contexts}

Several studies have been conducted in recent years to examine EFL teachers' readiness and disposition to implement TBLL, especially in countries where English is a foreign language. With regard to teachers' familiarity with the TBLL, Jeon and Hahn (2006)'s study revealed that most of the surveyed 288 Korean EFL teacher participants were well acquainted with the main principles of TBLL. However, in the paper by Liu et al. (2018), which examined data collected from 66 EFL Chinese teacher-respondents, it was found that the majority had a low level of understanding of TBLL. Still, the researchers noted that most of them reported their willingness to participate in training to deepen their knowledge about this approach and how to put it into practice. 
Surprisingly, teachers' favorable attitudes and prior knowledge of TBLL do not go hand in hand with a high level of use of this instructional method. The main barriers facing the implementation of TBLL are the public examination system, little knowledge of TBLL, difficulty in assessing students' performance, lack of confidence in how to use pedagogical tasks, lack of task-based activities in the current EFL textbooks, disciplinary problems, and the large class size (Jeon \& Hahn, 2006; Liu et al., 2018).

\section{RESEARCH METHOD}

\section{Survey Instrument}

The survey questionnaire was selected as a data collection instrument. On the one hand, it is time-saving: a large number can respond to it simultaneously and in a relatively short time. On the other hand, it ensures a high level of anonymity which allows respondents to answer the questions sincerely and honestly (Gray, 2004).

The questionnaire was adapted from Nunan's (2004) checklist for evaluating communicative tasks. It consisted of three sections. The first one intended to elicit background information about the respondents (sex, age group, years of experience, and place of work). The second section aimed at eliciting data about teachers' understanding of the concept of the task and familiarity with TBLL lesson format. The items are rated on a 5-point Likert scale ( $1=$ strongly disagree, $2=$ disagree, $3=$ undecided, $4=$ agree, and $5=$ strongly agree). The third section comprised 4 items: two direct questions about whether or not the participant uses tasks in their teaching practices and the frequency of doing so, and two multiplechoice questions in which teachers were asked to indicate the factors that drove or hindered them to implement TBLL.

\section{Data Collection and Analysis}

In this study, the snowball sampling technique, which involves asking "participants to identify others to become members of the sample" (Creswell, 2012, p. 146), was opted for data collection. The researcher resorted to sending the link of the designed Google Form survey to several EFL teachers who were requested to forward it to other instructors. The data then were computed and analyzed using descriptive statistics of frequencies and percentages.

\section{Participants}

A total of 90 high school EFL teachers were managed to be recruited for this study.

Table 1. Summary of Demographic Characteristics of the Sample

\begin{tabular}{lcc}
\hline & $\mathbf{N}$ & $\mathbf{\%}$ \\
\hline Gender & & \\
Male & 61 & $67.8 \%$ \\
Female & 29 & $32.2 \%$ \\
\hline
\end{tabular}




\begin{tabular}{lcc} 
Age & & \\
$21-29$ & 57 & $63.3 \%$ \\
$30-39$ & 20 & $22.2 \%$ \\
Over 40 & 13 & $14.4 \%$ \\
\hline Teaching Experience & & \\
$1-5$ & 59 & $65.5 \%$ \\
$6-10$ & 16 & $17.8 \%$ \\
$11-20$ & 9 & $10 \%$ \\
Over 20 & 6 & $6.7 \%$ \\
\hline Place of Work & & \\
An urban area & 50 & $55.6 \%$ \\
A rural area & 40 & $44.4 \%$ \\
\hline & &
\end{tabular}

\section{FINDINGS}

\section{Teachers' familiarity with the key concepts of TBLL}

Table 2. Percent of Teachers' Perceptions of the Key Concepts of TBLL $(n=90)$

\begin{tabular}{|c|c|c|c|c|c|}
\hline Item & SD & $\mathbf{D}$ & UN & $\mathbf{A}$ & $\mathbf{S A}$ \\
\hline TBLL is learner-centered & $1.1 \%$ & $6.7 \%$ & $2.2 \%$ & $40.4 \%$ & $49.4 \%$ \\
\hline $\begin{array}{l}\text { A task is a communicative goal-oriented } \\
\text { activity }\end{array}$ & $2.2 \%$ & $5.6 \%$ & $2.2 \%$ & $47.8 \%$ & $42.2 \%$ \\
\hline A task involves a primary focus on accuracy & $10 \%$ & $61.1 \%$ & $7.8 \%$ & $14.4 \%$ & $6.7 \%$ \\
\hline $\begin{array}{l}\text { A task is meant to provide students with an } \\
\text { opportunity to practice meaningfully a given } \\
\text { learned form. }\end{array}$ & $0 \%$ & $2.2 \%$ & $0 \%$ & $49.4 \%$ & $48.3 \%$ \\
\hline $\begin{array}{l}\text { A pedagogical task involves the use of all the } \\
\text { linguistic resources that students have to } \\
\text { complete. }\end{array}$ & $3.3 \%$ & $31.1 \%$ & $16.7 \%$ & $31.1 \%$ & $17.8 \%$ \\
\hline $\begin{array}{l}\text { A pedagogical task has a clearly defined } \\
\text { outcome }\end{array}$ & $2.2 \%$ & $10 \%$ & $10 \%$ & $44.4 \%$ & $33.3 \%$ \\
\hline
\end{tabular}

As can be seen from the table above, most respondents (90\%) rated TBLL as a learner-centered approach. Only $8 \%$ of the participants seemed to think that it is not the case. As a matter of fact, this is not a surprising result since all the recent approaches and methods of language teaching and learning are consistent with the learner centeredness philosophy. Reactions to items 2 and 3 show that the majority of the participants were aware that pedagogical tasks aim primarily at engaging learners in using language communicatively and meaningfully.

Items 4 and 5 were used to examine whether or not the participants differentiate between tasks and communicative activities. Only $2 \%$ of the respondents indicated that a task was not meant for practicing communicatively a language form they had already taught. However, the percentage of those who considered a task as an opportunity for students to use whatever language they have to complete it did not exceed half of the participants. The other half comprises $17 \%$ that opted for undecided as an answer. The results lend themselves to two readings. The first one is that the respondents believed that a task is meant essentially for practicing specific linguistic features, but the students are free to use other forms as well while carrying it out. The other tentative interpretation is that a task was understood as a general term that refers to both communicative 
activities in which learners are expected to produce a given learned linguistic feature communicatively and to tasks in which students are free to use all their linguistic resources to complete it.

Another defining characteristic of a task is the outcome. According to Skehan (1996) and Ellis (2003), the importance of this feature resides in the fact that it drives learners to consider language as a means of communication rather than a subject of study. The results show that the majority of the respondents $(70 \%)$ recognized outcome as one of the characteristics of tasks. The number of those who thought that tasks did not have a clearly defined outcome does not exceed $12 \%$.

\section{Teachers' Familiarity with the TBLL Framework}

Table 3. Percent of Teachers' familiarity with TBLL framework $(n=90)$

\begin{tabular}{|c|c|c|c|c|c|}
\hline Item & SD & D & UN & $\mathbf{A}$ & SA \\
\hline $\begin{array}{l}\text { TBLL offers the opportunity for 'natural' learning } \\
\text { inside the classroom }\end{array}$ & $0 \%$ & $9.2 \%$ & $8 \%$ & $57.5 \%$ & $25.3 \%$ \\
\hline $\begin{array}{l}\text { TBLL methodology includes a pre-task, a task } \\
\text { cycle, and a post-task. }\end{array}$ & $1.1 \%$ & $3.4 \%$ & $14.8 \%$ & $55.7 \%$ & $25 \%$ \\
\hline $\begin{array}{l}\text { TBLL methodology stands in total opposition with } \\
\text { the PPP (presentation practice production) model }\end{array}$ & $8.9 \%$ & $28.9 \%$ & $34.4 \%$ & $21.1 \%$ & $6.7 \%$ \\
\hline $\begin{array}{l}\text { TBLL methodology moves students from } \\
\text { accuracy exercises to fluency tasks }\end{array}$ & $2.3 \%$ & $11.5 \%$ & $21.8 \%$ & $51.7 \%$ & $12.6 \%$ \\
\hline
\end{tabular}

Unlike the traditional approaches to language learning in which language is dealt with as a subject of study, TBLL, through the employment of tasks, provides students with opportunities to use language the way it is used in the real world. The data indicate that most respondents, with a percentage of $82.8 \%$, concurred that the adoption of the TBLL could help in providing natural learning inside the classroom. Moreover, the results suggest that most respondents, with a percentage of over $80 \%$, were informed that the TBLL framework consists of three task phases (pre, while, and post). However, the fact that $38 \%$ did not think that the PPP and TBLL models were different, and more than a third of the participants opted for "undecided" as an answer implies that the teacherrespondents might be aware that the TBLL framework involves three task-phases, but not necessarily insightful about what each task-phase involves.

The respondents' reaction to item 6 confirms that there is a large number of participants who are ill-informed about the TBLL lesson format. Almost twothirds of the respondents confused the TBLL and the PPP procedures in the sense that it is the latter that moves students from accuracy exercises to fluency-based activities in the production stage. In addition to those who unmistakably can be claimed to be unfamiliar with how the TBLL lesson proceeds, $22 \%$, through choosing "undecided' as an answer, indirectly showed their lack of awareness about the difference between the two methodologies. 


\section{The incorporation of TBLL in the Moroccan EFL classroom}

The first two questions in the third section sought to determine whether teachers adopted tasks in their teaching practices and those who said "yes" were invited to indicate how often they did that. More than two thirds of the participants reported that they incorporated tasks in their classes. Interestingly, however, the data contained in the graph show that the frequency of using tasks is relatively low.

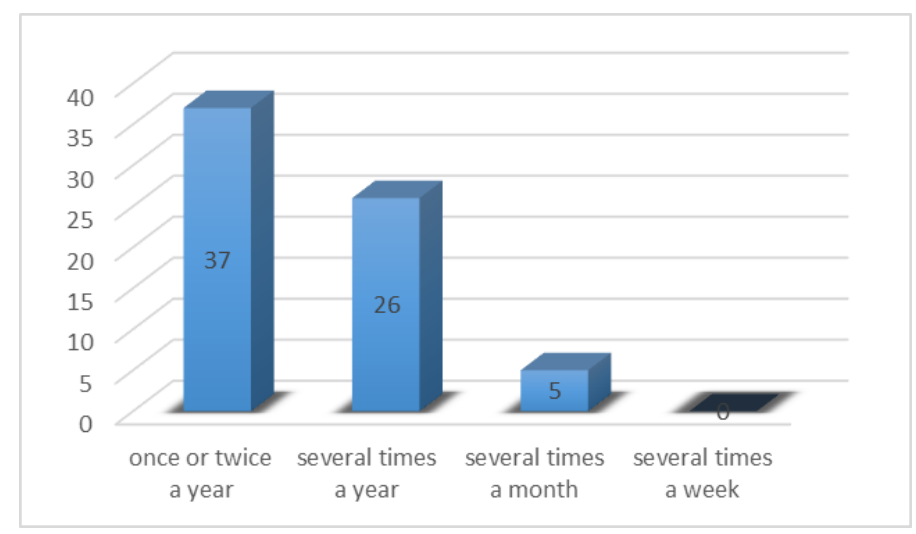

Figure 2. Teachers perceived frequency of use of tasks during a school year.

\section{Perceived factors to implementing TBLL in the Moroccan EFL classroom}

Concerning the reasons that are likely to boost the incorporation of TBLL in the Moroccan EFL classroom, participants were provided with a list of 4 options and were requested to add other ones.

Table 4. Reasons to adopt TBLL $(n=90)$

\begin{tabular}{lc}
\hline Option & Percent \\
\hline Tasks improve learners' interaction skills. & $71 \%$ \\
\hline Tasks encourage learners' intrinsic motivation & $44 \%$ \\
\hline Tasks create a collaborative learning environment & $75 \%$ \\
\hline $\begin{array}{l}\text { Tasks provide students with an opportunity to use language } \\
\text { communicatively }\end{array}$ & $76 \%$ \\
\hline Note: Participants could select as many options as were relevant to them.
\end{tabular}

As can be seen in the table above, the potential of TBLL to enhance students' communication and collaboration skills was selected by the majority of the participants. For a relatively significant number of teachers $(44 \%)$, the motivational characteristic of tasks is an important reason for implementing TBLL. Only a few teachers added other reasons for using TBLL. For example, they stated that:

- "tasks can also create a free anxiety zone or environment especially for shy students who find it difficult to get involved in classroom activities."

- “Tasks develop learners' independence." 
- "Tasks provide me with hints on how their language has developed."

\section{Perceived barriers to implementing TBLL in the Moroccan EFL classroom}

This item was meant to elicit data from teachers about what they perceived as barriers to implementing TBLL. It contained six potential obstacles and teachers were requested to add others as well.

Table5. Reasons to avoid implementing TBLL $(n=90)$

\begin{tabular}{lc}
\hline \multicolumn{1}{c}{ Option } & Percentage \\
\hline Students will resort to communicating in their L1. & $47 \%$ \\
\hline The Examination system is an obstacle to using tasks & $23.5 \%$ \\
\hline I have large classes. & $56 \%$ \\
\hline I have very little knowledge of task-based instruction & $13 \%$ \\
\hline Materials in textbooks are not suitable for using tasks & $56 \%$ \\
\hline \multicolumn{2}{r}{ Note. Participants could select as many options as were relevant to them. }
\end{tabular}

The results indicate that lack of task-based materials in the English textbooks, the crowded classes, and students' use of their mother tongue to complete the task are the principal motives that drive teachers to shy away from adopting TBLL with a percentage of $56 \%, 56 \%$, and $47 \%$ respectively. To a lesser extent, the traditional examination system was also selected by around a quarter of respondents. Only a few teachers cited "little knowledge of task-based instruction" as a reason to avoid using tasks. The other factors added included principally the syllabus and the classroom space. The comments below illustrate this:

- "The English syllabus is overloaded. I think more about how to cover it than anything else."

○ "Space in the classroom does not help."

\section{DISCUSSION}

With regard to the first research question, the results show that the participants have a fairly good grasp of the key concepts of TBLL. Thus, it could be argued that Moroccan EFL teachers are not lagging behind Koran and Chinese EFL teachers when it comes to their knowledge of this approach to language teaching and learning (Jeon \& Hahn, 2006; Liu et al., 2018). One possible explanation for this good level of familiarity with the defining traits of tasks is likely to be a result of the importance attached to tasks in the development of students' communicative competence in the official Moroccan English language guidelines documents. It is to be noted that the fact that a significant number of participants are not knowledgeable about the TBLL lesson format is not surprising. Littlewood (2004) acknowledged that a lot of teachers are likely to be ill-informed about TBLL, especially that the concept of task has been evolving over the last twenty years (Nunan, 1991). 
A large number of participants confirmed their use of tasks in their teaching. This can be regarded as a sign of their disposition to implement TBLL although the data revealed the frequency of adopting tasks is relatively very low. These findings are consistent with those of Jeon and Hahn (2006) who found that only half of a sample of 228 teachers at 38 different middle and high schools in Korea was "using task-based methods or techniques in their classrooms" (p. 134). The authors insightfully remarked that the fact that teachers were used to traditional approaches to language learning may make the adoption of TBLL difficult even if they were familiar with its key concepts.

On the question of what factors boost the incorporation of TBLL, this study found that teachers value primarily the pedagogical benefits of TBLL in enhancing students' communication and collaboration skills and to a lesser extent its motivational characteristic. These results are likely to be related to teachers' awareness that Moroccan students do not have many opportunities to use English outside the classroom setting. Hence, developing learners' interactive skills becomes the most important priority. This is in complete agreement with the idea of Ellis (2013) who contends that:

" ... where communicative opportunities outside the classroom are limited, there is an obvious need to provide such opportunities inside the classroom; TBLL is a means for achieving this. (p. 18)

Concerning the reasons that make teachers avoid TBLL, the findings show that the Moroccan EFL context does not promote frequent use of pedagogical tasks. Lack of task-based materials in the students' textbooks was an obstacle that was reported by a significant number of respondents. This may be interpreted as an indication that the currently used textbooks are not in line with the task based approach. Another more likely explanation is that teachers focus more on the lessons and the kind of activities that students would have in the exams especially that some teachers complained about the long and overloaded syllabus. As one of the participants remarked, teachers think more about how to cover it rather than designing tasks to engage learners in meaningful interaction.

The crowded classes and students' use of their mother tongue are also significant reasons that make teachers refrain from implementing TBLL. In this respect, Jeon and Hahn (2006) propose that instructors should "take group formation and presentation procedure into consideration" while lesson planning (p. 138). Teachers can also encourage students to use English by sensitizing them that the ultimate objective is enhancing their communicative competence. This is indeed time and energy-consuming but the pedagogical benefits of TBLL incorporation are definitely worth it.

Consistent with the findings of Liu et al. (2018)'s study, the traditional Moroccan assessment system represents another challenge facing the incorporation of TBLL by EFL teachers. A quick look at the past baccalaureate English national exams reveals that all that students are required to do is to answer comprehension questions, do some language exercises, and write a short essay. 


\section{CONCLUSION}

Notwithstanding the relatively small sample, this study has been the first attempt to offer insights into the current status of TBLL incorporation in the Moroccan EFL context. Overall, the results of this investigation demonstrate that teachers' good understanding of TBLL and recognition of its pedagogical benefits does not mean necessarily that they would frequently use it in their teaching practices. This study strengthens the idea of McDonough and Chaikitmongkol (2007) who contend that EFL teachers "require support when transitioning from traditional L2 teaching methods to task-based language teaching" (p. 124).

There is, therefore, a pressing need for assistance for EFL teachers in order to be able to regularly and efficiently apply TBLL. The ministry of education should organize pre-service and in-service training programs for EFL teachers to deepen their knowledge of TBLL principles in general and its three phases lesson format in particular and for learning how to design and assess tasks. Given the fact that many teachers reported that the lack of task-based materials is one of the important obstacles to adopting TBLL, ready-made materials should be made available for teachers to save them some time and energy. Teachers also need practical tips on how to manage their students while their students are working on the task.

\section{REFERENCES}

Brown, H. D. (2006). Principles of language learning and teaching. White Plains, N.Y: Pearson Education.

Creswell, J. W. (2012). Educational research: Planning, conducting, and evaluating quantitative and qualitative research (4th ed.). Boston, MA: Pearson Education, Inc.

Ellis, R. (2003). Task-based language learning and teaching. Oxford: Oxford University Press.

Ellis, R. (2015). The importance of focus on form in communicative language teaching. Eurasian Journal of Applied Linguistics, 1(2),1-12.

Gray, D. E. (2004). Doing research in the real world. London: SAGE Publications, Inc.

Jeon, I. J., \& Hahn, J.W. (2006). Exploring EFL teachers' perceptions of taskbased language teaching: A case study of Korean secondary school classroom practice. Asian EFL Journal, 8(1), 123-143.

Jordan, G. (2004). Theory construction in second language acquisition. Amsterdam: John Benjamins.

Larsen-Freeman, D., \& Anderson, M. (2011). Techniques and principles in language teaching ( $3^{\text {rd }}$ ed.). Oxford: Oxford University Press.

Lightbown, P. M., \& Spada, N. (2006). How languages are learned (3 ${ }^{\text {rd }}$ ed.). Oxford: Oxford University Press. 
Littlewood, W. T. (2004). The task-based approach: Some questions and suggestions. ELT Journal, 58(4), 319-326. https://doi.org/10.1093/elt/58.4.319.

Liu, Y., Mishan, F., \& Chambers, A. (2018). Investigating EFL teachers' perceptions of task-based language teaching in higher education in China. The Language Learning Journal, 1-16.

Long, M. H. (1983). Native speaker/non-native speaker conversation and the negotiation of comprehensible input. Applied Linguistics, 4(2), 126-141. https://doi.org/10.1093/applin/4.2.126

McDonough, K., \& Chaikitmongkol, W. (2007). Teachers' and learners' reactions to a task-based EFL course in Thailand. TESOL Quarterly, 41(1), 107132.

MoE. (2007). English language guidelines for secondary schools: Common core, first year, and second year baccalaureate. Available at http://www.zenglish.co.uk/2018/12/english-language-guidelines-for.html [Verified 10 February 2021]

MoE. (2009). Pedagogical guidelines for middle school. Available at http://www.zenglish.co.uk/2018/12/pedagogical-guidelines-formiddle.html [Verified 10 February 2021]

Nunan, D. (1991). Communicative Tasks and the Language Curriculum. TESOL Quarterly, 25(2), 279-295. https://doi.org/10.2307/3587464

Nunan, D. (2004). Task-Based Language Teaching. Cambridge: Cambridge University Press.

Raya, M. J. (2009). Task-Based Language Learning: An Interview with Rod Ellis. GRETA Journal. Available at https://www.academia.edu/5028444/Task_Based_Language_Learning_An Interview_with_Rod_Ellis [Verified 03 February 2021]

Richards, J. C., \& Rodgers, T. S. (2001). Approaches and Methods in Language Teaching ( $\left.2^{\text {nd }} e d.\right)$. Cambridge: Cambridge University Press.

Skehan, P. (1996). A Framework for the Implementation of Task-based Instruction. Applied Linguistics, 17(1), 38-62. https://doi.org/10.1093/applin/17.1.38

Willis, D., \& Willis, J. (2001). Task-based language learning. In D. Carter \& D. Nunan (Eds.), The Cambridge Guide to Teaching English to Speakers of Other Languages. Cambridge: Cambridge University Press.

Willis, J. (2004). Perspectives on task-based instruction: Understanding our practices, acknowledging different practices. In B. L. Leaver \& J. Willis (Eds.), Task-based instruction in Foreign Language Education: Practices and programs (pp. 3-46). Georgetown University Press.

Willis, J. (1996). A framework for task-based Learning. London: Longman. 